\title{
The Management of Water Points in Niger under the Communalization
}

\author{
Zakari Aboubacar $^{1}$ \\ ${ }^{1}$ Department of Sociology, University of Zinder, Republic of Niger \\ Correspondence: Zakari Aboubacar, Department of Sociology, University of Zinder, PO BOX 656, Republic of \\ Niger. E-mail: aboubacar.zakari@gmail.com
}

Received: March 6, $2013 \quad$ Accepted: May 15, $2013 \quad$ Online Published: June 28, 2013
doi:10.5539/ass.v9n9p94

\begin{abstract}
This paper seeks to analyze the management of water points in Niger according to the communalization process. It explains how the new reform of management in the supply of water, as a government policy, in the local areas raises new issues in Sahel and Niger countries. It looks into the issue of water supply which is at the heart of public policy to the countryside. It analyzes not only the importance of water points in Niger but also some sources of concern in the use according to the different logics involved. The paper further relates the role of media in social change according to the using of water in order to protect climate change. The paper concludes that, if, the aim for central and local authorities is to achieve local development, the confrontation between these two approaches must contribute to achieve the desired effect. The paper recommends that in order to solve this social problem, the mayors and central authorities must take into consideration the reaction of the different actors and should install in all the country the Land Commission under the Rural Safety Program.
\end{abstract}

Keywords: water management, communalization, social significance and logics

\section{Introduction}

In accordance with its climate, the major water resources in Niger is River Niger and several lakes, ponds, goulbis and numerous water spread over the territory. These water bodies are used as source of drinking and farming by the population. It should be noted that Niger's population practices an agro-forestry pastoral oriented activities, in other words it can be said that farmers and nomads live in those areas. Farmers and nomads have each others logic in using water. These two approaches are now regulated by the State and its departments, especially with the new policy of communalization committed since 2004. Such regulation or management of water points by the various actors do not go smoothly. In this paper, I first try to make a brief presentation of Niger, explain the materials and the method used, define the concepts above. Then, I talked about the mechanism of managing water in both traditionally and modern before talking about the management of water under the communalization.

\section{Statement of the Problem}

Niger is a landlocked country in the Western part of Africa, sharing border with Nigeria and Benin to the south, with Mali and Burkina Faso to the west, with Algeria and Libya to the north and Chad to the east. Niger is the largest nation in West Africa with an area of about 1,267,000 km2; also, the population of Niger is estimated at about 15,000,000 in 2011 .

Niger is a developing country with over $80 \%$ of its territory covered by the Sahara desert. But it should be noted that Niger's population practices an agro-forestry pastoral oriented activities, in other words, farmers and nomads live in those areas. Farmers and nomads have each other's logic in using water. In this case, water and space must be protected in order to have a good management of these resources in a decentralized system.

Management of water in a decentralized system must be understood as the meeting of different stake holders to secure a property. In a sociological approach, it can be defined as from its institutionalized nature, for the function it fulfills but also and especially through the means of access to the water by different actors.

However, there are some problems in this management. Nomadic people using water are not exactly defined because there are some taxes that must be paid in each area. We can also add how to use public water in our village because in the traditional mode water is not the subject of numerous protocols. In this case, we must ask 
how to make a water management in this system in order to have good achievement? What is the status of Water Sources, the sources of concern and the logic of confrontation?

\section{Materials and Method}

This research work is a product of literature materials collected from library data such as text books, journals, periodicals, magazines, government reports and others. Since my research work deals with a sociological analysis, my methodology is based on a socio-anthropological approach. It is characterized by the fact that it combines sociological and anthropological research. (Sardan, 1995: 11). I used it because it is difficult for a sociologist to discuss a study under a purely sociological perspective. The aim is to explain a social fact by another in order to determine the relationship between them.

\section{Brief Overview of Niger}

Niger is divided into 7 regions and a capital district, Niamey. The regions are subdivided into 36 departments. As of 2004, the 36 departments are divided into 266 communes. According to the communalization, there are 52 urban communes and 214 rural communes. In this system, management of resources like water has a big interest.

\section{Mechanism for the Management of Water with the Communalization}

\subsection{Back Ground}

Management of water in Niger has a history. It should be noted that the idea of creating a public body responsible for promoting the development of the resources of the Niger River Basin dated back to colonial times. In the early fifties, the Mission Study and Development of Niger, based in Bamako, had jurisdiction over the stretch of river from its source in Guinea to the Nigerian border.

Following the independence in the 1960s, the riparian states have adopted "The Act of Niamey" in which they acknowledged the international character of the river and the need for a common regulation for use. In the absence of convincing results the nine riparian states (Benin, Burkina Faso, Cameroon, Ivory Coast, Guinea, Mali, Niger, Nigeria and Chad) decided in 1980 in the town of Faranah near the source of the river, to found the Niger Basin Authority (NBA). But the new institution will know fairly quickly a very long period of financial and political crisis, seriously affecting regional cooperation. "Since 1998, it has found new momentum and the last summit in Niamey dedicates its new ambitions". (Robert, 2009). In this case, the objective of the Charter of the Niger Basin Water, which includes 37 items, is to promote cooperation based on solidarity and reciprocity for sustainable, equitable and coordinated water resource catchment basin of Niger. The nine states commit themselves to respect a number of fundamental principles, including:

1) Participation of the people concerned,

2) Fair use, reasonable and non-damaging water resources

3) To maintain the quantity and quality of these resources to the highest possible levels

4) Preservation, protection and improvement of aquatic ecosystems and wetland

5) The gradual reduction of transboundary pollution

6) Prevention and mitigation of harmful situations like floods, droughts, Siltation and climate change

7) Application of the polluter pays and pays sampler

8) Using the best available techniques an economically acceptable cost.

Despite all these proposals the river was in maintenance suffers. The investment program adopted in Niamey is divided into no fewer number than 639 actions that will lead into four five-year plan through 2027. It will mainly reforest riverbanks to recover the degraded plains and sand out the middle basin including the loop of Niger in Mali north-eastern Basin in Burkina Faso and the right bank of River Niger, upstream of Niamey. Only one fifth of program funds are being acquired, the rest should be raised at a meeting of donors which will be held after. There is great urgency as the river flow has decreased by $20-55 \%$ over the past 40 years, mainly because of climate change and population pressure and the overall findings were alarming:

1) Low flows and severe silting

2) Floating vegetation and Industrial Pollution

3) Navigation and fish breeding almost impossible for lack of sufficient flow

4) Extreme poverty of local populations

5) under-exploitation of agricultural potential of the basin 
6) Communal conflicts around the few water points

In addition to the above mentioned estimates we can be a little optimistic because, we expect in the region not only to a doubling of population in the next twenty years, but also to a massive influx of "environmental refugees", and thus to uncontrolled occupation of land and overexploitation of resources. The Niger Basin Authority which includes the nine riparian states does not seem to be able, in using its own resources, to meet those challenges and isolated actions of governments which are ineffective in preventing the river run its loss. This background shows that management of water is very important in a country like Niger.

\subsection{Status of Water Sources}

The management of water sources in Niger is regulated by Decree No.97-368/PRN/MHE of 2 October 1997 establishing the modalities for the implementation of the ordinance no. 93-014 of 14 March 1993, especial articles 37 and 50. Thus the public waters belong to communities within a territories located and are subject to allotment management communities, the beneficiaries who manage the water must ensure for its management and maintenance. The beneficiaries are represented by management committees which are in fact responsible for ensuring the sustainability of result. The implementation of these committees is the guarantee of transparency and involvement of the entire community, this situation is a general case in Niger.

But, Moustapha Moussa said that in the town of Dirkou, water is seen primarily on its traditional status before integrating it into its modern status. Traditionally, "Water is not a commodity in the desert, to refuse neighbor water or asks for something in return is committing a crime."(Moustapha, 2006: 36).Water, oasis of ponds is used by every person in accordance with its needs without discrimination or restriction because it is a collective interest.

In this case, Antoine Raogo SAWADOGO "describes the characteristics which obey this property". (Antoine, 2002: 108). He first talked about its necessity in the sense that water is essential for individual and collective survival. Further he added that the group feels threatened if it is beyond its control and may be wholly or partially absorbed by another group which becomes an enemy. Then; he explained that the collective interest is always preceded by "our". He also talked about its production because it is done collectively as each member of the community. The morality obliged everyone to help create it according to its possibilities. Speaking of the management he said that it is subject to a requirement that may suffer any exception.

From accessibility to the management of the collective interest, we should appreciate one thing: water should not be wasted. If you have access to this product, there is a purpose for you as an individual and collective security. Without these characteristics, he concluded, all collective interests have sacred character. It's proceeded directly from God who provides, man is only user, protector, and manager. These are the characteristics of a collective interest, such as water in our societies. This system tends to change by adopting new standards of governance in local communities because water became as a private things. The municipality as a local authority must provide public services that meet the needs of the population, in terms of hydraulics. The municipality has jurisdiction to participate in the production or distribution of drinking water.

\subsection{Sources of Concern}

The communalization or what is called in the administrative language; decentralization, has taken place in a context where there is a natural resource management that has its own dynamics. There are two types of spaces and mode of access to land emerges. Territorialized geopolitical space, that seems to be universally recognized by the locals. As noted by Sidikou, reported by Moustapha Moussa, "Land tenure is complex in that the management of the land can be done independently of the part for those deals, the management of which may vary with the soil type and the other from the date palms". (Sidikou, reported by Moustapha, 2006: 47). For example, the ownership of a palm tree or a well does not necessarily imply access to land ownership, it has its entitled prerogatives. He added that, during the installation of the conduct of water, a resident of a district has refused tuner through his land simply because he has no plans to fire hydrant in his district. In addition, the emergence of a new factor, thus, the arrival of a foreign community to the local environment can be a source of concern to the extent that it must find land to settle not only but also to highlight, even though there are rules that govern the use or at least access. These factors mentioned above must be taken into account by the mayors in their own district when they plan to create a water point in a locality in order to realise good benefit.

\subsection{Logic of Confrontation}

The object in question is of vital importance in the sense that people call the water the source of life. Thus the traditional method of use is confronted with the modern mode. The resources such as ponds are the property of people and no restriction was made when the mode of access in the traditional system. "The domestic water, 
more than anywhere else, the water in the desert that's life and its management covers a social violation of any use for commercial purposes said" (Moustapha, 2006: 47).Indeed, the transfer of potable water supply to the town will be felt by users as a privatization of water sector, and beyond the loss of its social character for which it was originally built to become a commodity. The management of a resource such as water is the responsibility of the Assembly of those rights in a given space. Most conflicts are explained by whether or not the villagers have access to some of these properties like conflict breeders and farmers. In a world where all products and services have a market value, grassroots communities have no benchmarks for social values.

Another factor in the context of this communalization through the management of water points and spaces is the status of transhumant which is not clearly defined. According the facts that pastoralist and communalization evolved two systems of social organization, economic and political opposites, communalization will pose two problems for transhumant pastoralists: the redefinition of their space of belonging and investment and other benefits in the context of the communalization. Only a setting of legal rules will resolve this problem because for the pastors, the space is open and infinite. In this case, the responsibility of the Central State is to create a consensual management of the sector.

\subsection{The Relationship between Water Resources in Climate Change: The Role of Mass Media in Social Change}

In order to inform, educate and share with men and women of the media on the relationship between climate change and water resources, in general, taking the example of Integrated Water Resources Management (IWRM) in Niger, specifically, the Global Water Partnership (GWP) in collaboration with the European Union, organized a workshop for media men from 11 member countries of Economic Community of West African States (ECOWAS) in 2008. It appears from the foundation with climate change, African people; particularly those located in the Niger Basin are threatened by declining water resources and the proliferation of waterborne diseases.

Today, climate change is a major concern for African countries. Particularly those in the Sahel where the economy is based on rainfed agriculture. In these countries, the negative effects of the phenomenon are considerable. It should be noted, among other food security and lack of water resources.

To identify the relationship between climate change and water resources, in general, taking the example of IWRM in the Niger specifically, the Global Water Partnership (GWP) in collaboration with the European Union organized a workshop for media men from 11 member countries of ECOWAS.

This foundation, which takes place in Niamey, Niger from Monday, July 28, 2008, led the participants to better understand the phenomenon of climate change, through the causes, effects, manifestations and impacts".(News paper Independent of Mali, accessed on 31 July 2008.)

It is the former Dean of the Faculty of Agriculture at the University of Niamey, Adamou Amoukou Ibrahim, who submitted the communication on climate change. He said this concept is defined as changes in climate in different parts of the planet. It is manifested by the sun's rising temperatures, high winds and flooding.

He also questioned about the effects of emissions that are rising because of human activities (oil combustion and deforestation).Compared to the relationship between climate change and integrated management of water resources, he support with climate change, fresh water becomes increasingly scarce. Therefore, the water unfit for consumption will infiltrate freshwater, what will cause the proliferation of waterborne diseases, including yellow fever, cholera, and hepatitis B, and so on. At the same time, the water resources decrease considerably.

In the same way, the President of the National Partnership for Water in Niger, Dr Yahaya Tounkara said, his organization will focus more on promoting the integrated management of water resources, an approach considered most appropriate for the preservation of water resources and ecosystems of which they are attached and conflict resolution open or latent in the use of water resources in the world.

\section{Analysis}

The water management in Niger as stated above has an importance not only in a central authority but also in the context of decentralization. The creation of a modern well in a village or a mini water supply provokes many reactions. It has both advantages and disadvantages. Tidjani Alou calls them as public property. For him, community infrastructure and management in many villages causing mutations scene involving various social actors by learning new social roles and has constantly comparing themselves and also has other non-actors villagers that they do not usually access.

The author added that the structures set up around the management of water, far from being just play spaces between diverse social actors, promote, through a process of collective ownership, the emergence of new 
values-oriented roots of the concept of public interest in the village. We can remember the issue of social mobilization that could lead to the production of social change in the village. If the author mentioned above speaks about the public interest, the mayor of the rural commune of Adjekoria, talks about the benefits of mini water supply in its commune. For him, the presence of this new tool has revolutionized style life of his commune by improving once the conditions of life of its citizens.

But when talking about innovation and introduction of new products in the rural, we must not only see about advantages. There are also disadvantages. For example, how many farmers are there in a given locality who can afford to go to the fountain at their discretion so that the traditional well is at his door? How to sustain the work and involve the mass to the public interest in an under developed country like Niger? The government and media can contribute to solve the problem by educating the people in order to meet the challenge.

\section{Conclusion}

In concluding this paper it should be remembered that, the management of natural resources, particularly water in Niger is referred to according to two logics: the traditional logic with all the cultural characteristics and the modern one. If the aim for central and local authorities is to realize local development, the confrontation between these two approaches must contribute to achieve the desired effect. Neither of these two approaches can replace the other. The government can only create the conditions for a possible integration of these logics because it must adopt a management scheme which will reflect the repositioning of various actors responsible for the management of public spaces in general and the resolution of new reports in particular. The absence of a specific hydraulic law in a community can explain the dysfunction of the management of water point in Niger. In this case, the government can install in all the country the Land Commission under the rural safety program. As reminder that in the context of the land in Niger, the State has developed a rural safety code to that effect.

\section{References}

Dessouassi, R. (2009, November 9-13). Problem of the management of resources concerted ground water Niger basin. Resp. Observatory of the Niger Basin. Proceedings of the 2nd African Water Week, Johannesburg.

Moustapha, M. (2006). problem of decentralized management of the mini water supply to the town of Dirkou. Memory, DEA, Geography, University Abdou Moumouni Niamey.

Republic of Niger. (1991). Water resources of north eastern Niger, Niamey. Ministry of Water and Environmental BGRM.

Republic of Niger. (2003). Rural Development Strategy (RDS) Niamey. Office of the Prime Minister.

Sardan, J. (1995). Anthropology and development, essays in anthropology of social change. Paris: Khartala.

Sawadogo, R. A. (2002). The African state to face decentralization. Paris: Khartala.

\section{Copyrights}

Copyright for this article is retained by the author(s), with first publication rights granted to the journal.

This is an open-access article distributed under the terms and conditions of the Creative Commons Attribution license (http://creativecommons.org/licenses/by/3.0/). 